\title{
All in the spin
}

\author{
Derek Richards \\ Editor, Evidence-based Dentistry
}

Evidence-Based Dentistry (2005) 6, 29-30. doi:10.1038/sj.ebd.6400330

The recent quarterly release of the Cochrane Library (April 2005) has four new dental reviews, namely, Antibiotic Use for Irreversible Pulpitis, ${ }^{1}$ Interventions for Treating Asymptomatic Impacted Wisdom Teeth in Adolescents and Adults, ${ }^{2}$ Recall Intervals for Oral Health in Primary Care Patients ${ }^{3}$ and Sedation of Anxious Children Undergoing Dental Treatment. ${ }^{4}$ These will be covered in Evidence-based Dentistry in future issues. In addition to these, the Cochrane Library also contains one updated review, Manual versus Powered Toothbrushing for Oral Health. ${ }^{5}$ Regular readers will be aware that one of the strengths of Cochrane reviews is the commitment to keeping the reviews updated. The initial powered toothbrushing review ${ }^{6}$ was published in January 2003, achieving an exceptionally high media profile. Although it did not meet the dizzy heights of the initial review, the update did again achieve wide media coverage here in the UK.

A close look at the results and conclusions from the two abstracts of the two versions (Table 1) shows that 13 extra trials, involving around 1300 additional patients, have been included. The results show that powered toothbrushes with a rotation-oscillation action reduce plaque and gingivitis more than manual toothbrushing, with an $11 \%$ reduction in the
Quigley Hein plaque index and a 17\% reduction on the Ainamo Bay bleedingon-probing index as in the 2003 review.

Although this update continues to show an increased benefit for the use of powered toothbrushes with rotation-oscillation over manual brushes there are no data as yet on the long-terms effects of powered toothbrushing. It is worth highlighting, as the authors do in their discussion, that there is overwhelming evidence that toothbrushing reduces gingivitis, ${ }^{7}$ may prevent periodontitis and certainly prevents tooth decay if it is carried out in conjunction with fluoride toothpaste. The authors also add that these benefits occur whether the brush is

Table 1. Comparison of the results and conclusions of the 2003 and 2005 versions of the Cochrane review of manual versus powered toothbrushing.

\begin{tabular}{|c|c|c|}
\hline & \multicolumn{2}{|c|}{ Review } \\
\hline & 2003 & 2005 \\
\hline $\begin{array}{l}\text { Review } \\
\text { reference }\end{array}$ & $\begin{array}{l}\text { Heanue M, Deacon SA, Deery C, et al. Manual versus powered } \\
\text { toothbrushing for oral health (Cochrane Review). In the Cochrane } \\
\text { Library. Oxford: Update Software; 2003, issue 1: }\end{array}$ & $\begin{array}{l}\text { Robinson PG, Deacon SA, Deery C, et al. Manual versus powered } \\
\text { toothbrushing for oral health. Cochrane Database Syst Rev 2005; } \\
\text { issue 2: }\end{array}$ \\
\hline Results & $\begin{array}{l}\text { Data for meta-analysis from } 29 \text { trials ( } 2547 \text { participants). } \\
\text { Brushes with rotation-oscillation action removed more plaque } \\
\text { and reduced gingivitis better than manual brushes in short and } \\
\text { long term. } \\
\text { Plaque at } 1-3 \text { months: } \mathrm{SMD},-0.44(95 \% \mathrm{Cl},-0.66 \text { to } 0.21) \text {; } \\
\text { gingivitis: } \mathrm{SMD},-0.44(95 \% \mathrm{Cl},-0.72 \text { to }-0.15) \text {. These represent } \\
\text { a } 11 \% \text { reduction on the Quigley Hein plaque index and a } 6 \% \\
\text { reduction on the Löe and Silness gingival index. } \\
\text { Plaque after } 3 \text { months: SMD, }-1.15(95 \% \mathrm{Cl},-2.02 \text { to }-0.29) \text {; } \\
\text { gingivitis: SMD, }-0.51 \text { ( } 95 \% \mathrm{Cl},-0.76 \text { to }-0.25) \text {. These represent } \\
\text { a } 7 \% \text { reduction on the Quigley Hein plaque index and a } 17 \% \\
\text { reduction on the Ainamo Bay bleeding-on-probing gingival index. } \\
\text { Heterogeneity in these meta-analyses for short-term trials caused } \\
\text { by one trial with exceptionally low SD. Sensitivity analyses revealed } \\
\text { results to be robust when selecting trials of high quality. There was } \\
\text { no evidence of any publication bias. } \\
\text { No other powered brush designs were consistently superior to } \\
\text { manual toothbrushes. In these trials, data on cost, reliability and } \\
\text { side effects were inconsistently reported. Side effects reported were } \\
\text { localised and temporary. }\end{array}$ & $\begin{array}{l}\text { Data from } 42 \text { trials ( } 3855 \text { participants). Brushes with rotation- } \\
\text { oscillation action removed plaque and reduced gingivitis more } \\
\text { effectively than manual brushes in short term and reduced } \\
\text { gingivitis scores in studies of }>3 \text { months. } \\
\text { Plaque at } 1-3 \text { months: } \mathrm{SMD}, 0.43(95 \% \mathrm{Cl}, 0.72 \text { to }-0.14) \text {; } \\
\text { gingivitis: SMD, } 0.62(95 \% \mathrm{Cl}, 0.90 \text { to }-0.34) \text {. These represent an } \\
11 \% \text { difference on the Quigley Hein plaque index and a } 6 \% \\
\text { reduction on the Löe and Silness gingival index. } \\
\text { Plaque after } 3 \text { months: SMD, }-1.29(95 \% \mathrm{Cl},-2.67 \text { to } \\
0.08 \text { ); gingivitis: SMD, }-0.51 \text { ( } 95 \% \mathrm{Cl},-0.76 \text { to }-0.25) \text {. These } \\
\text { represent a } 17 \% \text { reduction on the Ainamo Bay bleeding-on- } \\
\text { probing index. } \\
\text { Heterogeneity existed between trials for short-term follow-up. } \\
\text { Sensitivity analyses revealed results to be robust when selecting } \\
\text { trials of high quality. There was no evidence of any publication } \\
\text { bias. } \\
\text { No other powered toothbrush designs were as consistently } \\
\text { superior to manual toothbrushes. } \\
\text { Cost, reliability and side effects were inconsistently reported. } \\
\text { Reported side effects were localised and temporary. }\end{array}$ \\
\hline $\begin{array}{l}\text { Authors' } \\
\text { conclusion }\end{array}$ & $\begin{array}{l}\text { Powered toothbrushes with a rotation-oscillation action achieve a } \\
\text { modest reduction in plaque and gingivitis compared with manual } \\
\text { toothbrushing. } \\
\text { Observation of methodological guidelines and greater standar- } \\
\text { disation of design would benefit both future trials and meta- } \\
\text { analyses. }\end{array}$ & $\begin{array}{l}\text { Powered toothbrushes with a rotation-oscillation action reduce } \\
\text { plaque and gingivitis more than manual toothbrushing. } \\
\text { Observation of methodological guidelines and greater standar- } \\
\text { disation of design would benefit both future trials and meta- } \\
\text { analyses. }\end{array}$ \\
\hline
\end{tabular}

SMD, standard mean difference; $\mathrm{Cl}$, confidence interval; SD, standard deviation. 
manual or powered and the results of this review do not indicate that toothbrushing is only worthwhile with a powered toothbrush.

Despite the clarity of the reviews and that fact that there is little change in the conclusions over the 2-year interval between them, the reviews have been interpreted in widely divergent fashion. The Observer headline ${ }^{8}$ stated that, "Electric gadgets get the brushoff" whereas the Smile-on website (www.smile-on.com/ news/news_view.php?news_id=2226) was reporting, "Electric toothbrushes better at plaque reduction". Smile-on's interpretation is all the more interesting since, after the 2003 review, it reported (www.smile-on.com/news/news_view.php? news_id=1192) "Powered toothbrushes no better than manual". The reporters for The Guardian have taken the view that the powered brush offers no advantage over the manual brush, a position adopted by several commentators when the initial version was published. This was the case even though a difference in favour of powered brushes was noted in the Cochrane review.
Interpretation of systematic reviews in general and Cochrane reviews in particular is something that I have touched on previous editorials. Interpretation of the results of reviews where results are not very clear cut is an issue that cuts to the essence of the evidence-based approach - a point regularly misinterpreted by people who do not support the approach. A key phase of the evidence-based approach has always been a careful appraisal of the evidence, together with consideration of the ability to implement the treatment and the patient's wishes and desires. What we have with the assessment of powered versus manual toothbrushing is a good example of a review that shows a small benefit for powered brushes which may or may not be long-term (as we do not yet have the evidence), together with cost and compliance issues.

Although the summaries of such reviews published in the journal offer a quick overview for the busy practitioner, those who have time to do so should read the full reviews. These provide much background information and in- formed discussion, which puts the practitioner in a far better position to discuss the advantages and disadvantages of new treatments or technologies with their patients and counter the varied press based opinions as noted above.

1. Keenan JV, Farman AG, Fedorowicz Z, Newton JT. Antibiotic use for irreversible pulpitis. Cochrane Database Syst Rev 2005; Issue 2.

2. Mettes TG, Nienhuijs MEL, van der Sanden WJM, Verdonschot EH, Plasschaert AJM. Interventions for treating asymptomatic impacted wisdom teeth in adolescents and adults. Cochrane Database Syst Rev 2005; Issue 2.

3. Beirne P, Forgie A, Clarkson JE, Worthington HV. Recall intervals for oral health in primary care patients. Cochrane Database Syst Rev 2005; Issue 2.

4. Matharu LM, Ashley PF. Sedation of anxious children undergoing dental treatment. Cochrane Database Syst Rev 2005; Issue 2.

5. Robinson PG, Deacon SA, Deery C, et al. Manual versus powered toothbrushing for oral health. Cochrane Database Syst Rev 2005; Issue 2.

6. Heanue M, Deacon SA, Deery C, et al. Manual versus powered toothbrushing for oral health (Cochrane Review). In the Cochrane Library. Oxford: Update Software; 2003; Issue 1.

7. Lang NP, Cumming BR, Löe H. Toothbrushing frequency as it relates to plaque development and gingival health. J Periodontol 1973; 44:396-405.

8. Revill J. Electric gadgets get the brushoff. Observer 2005; April 17. 